\title{
COMPARATIVE STUDY OF RC FRAMED STRUCTURES USING SPECTRA BASED PUSHOVER ANALYSIS
}

\author{
Pavan Kumar N ${ }^{1}$, Avinash Gornale ${ }^{2}$, Gargi G S ${ }^{3}$, B G Naresh Kumar ${ }^{4}$ \\ ${ }^{1} P G$ Student, Dept. of Civil Engineering, BGS Institute of Technology, Mandya District, Karnataka, India \\ ${ }^{2}$ Asst. Professor, Dept. of Civil Engineering, Maharaja Institute of Technology, Mysore District, Karnataka, India \\ ${ }^{3}$ Asst. Professor, Dept. of Civil Engineering, BGS Institute of Technology, Mandya District, Karnataka, India \\ ${ }^{4}$ Prof \& Principal, Dept. of Civil Engineering, Maharaja Institute of Technology, Mysore District, Karnataka, India
}

\begin{abstract}
Spectra based multimodal adaptive pushover analysis considers higher modes of vibration and combines them using SRSS rule and scale factors. Damage index for the structures are calculated to evaluate the degree of damage occurred after a seismic event. For the present study the Spectra based multimodal adaptive pushover analysis is adopted for G+ 4 storeys Symmetric and $G+4$ storeys Asymmetric Reinforced concrete framed structures. The Expended Energy based damage index methods are used to calculate Damage Index for symmetric and asymmetric structures. ETABS 2015 software is utilized for modeling and analysis of Reinforced concrete framed structures. The comparative studies are carried out between the structure considering only 1 st mode and considering all modes and compared between 3 methods of damage index. It is observed that the capacity obtained by considering all modes is less than the capacity obtained by considering only 1st mode. The target displacement obtained considering only 1 st mode is less than the target displacement obtained considering all modes. And the damage index obtained by considering all modes is more than the damage index obtained by considering only 1st mode. Therefore it is necessary to consider all modes to get accurate results. In asymmetric building the ductility is less, the capacity is less, demand is high, and degree of damage is more when compared with symmetric building.
\end{abstract}

Keywords: pushover analysis, damage index, RC frame, multimodal, symmetric and asymmetric

\section{INTRODUCTION}

The Spectra based multimodal adaptive pushover analysis which is proposed by K. Shakeri, M. Mohebbi Asbmarz and M.A. Shayanfar 2008[3] is adopted for G+4 storey Symmetric and G+4 storey Asymmetric building in the analysis of Reinforced concrete framed structures. The Expended Energy based damage index methods which is proposed by Anthugari Vimala, Pradeep Kumar, Ramancharla (2014) [10] are used to calculate Damage Index for symmetric and asymmetric structures. ETABS 2015 software is utilized for modelling and analysis of Reinforced concrete framed structures.

Spectra based multimodal adaptive pushover analysis considers higher modes of vibration and combines them using SRSS rule and scale factors. All these factors are very essential to increase the accuracy of the results. Damage index for the structures are calculated to evaluate the degree of damage occurred after a seismic event. The Expended energy based damage index is represented as ratio of inelastic energy dissipated at any displacement to the total inelastic energy capacity of the structure. The energy method is used to calculate Global damage index of the structure.

This project work focuses on Evaluation and Comparative study of damage index of symmetric and asymmetric RC framed structures using Spectra based multimodal adaptive pushover analysis.
In our present study we have adopted two example reinforced concrete framed structures (i) 5 storey symmetric structure and (ii) 5 storey asymmetric structure. Spectra based multimodal adaptive pushover analysis used as RC framed analysis. ETABS 2015 is utilized for modelling and analysis. Damage indices are calculated and compared with symmetrical and asymmetrical structures.

\section{MODELS CONSIDERED FOR STUDY}

\subsection{Symmetric Model}

A G+4 storey, 7-bay by 2-bay symmetrical reinforced concrete framed residential building is considered.

\begin{tabular}{|l|l|}
\hline $\begin{array}{l}\text { Dimension of } \\
\text { Column }\end{array}$ & 0.23 X 0.4 m \\
\hline Dimension of Beam & $0.23 \times 0.35 \mathrm{~m}$ \\
\hline Thickness of slab & $0.125 \mathrm{~m}$ \\
\hline Thickness of wall & $0.23 \mathrm{~m}$ \\
\hline Soil type & II \\
\hline Live load & $2 \mathrm{KN} / \mathrm{m}$ \\
\hline Location of building & Mysore, Karnataka, India. \\
\hline
\end{tabular}




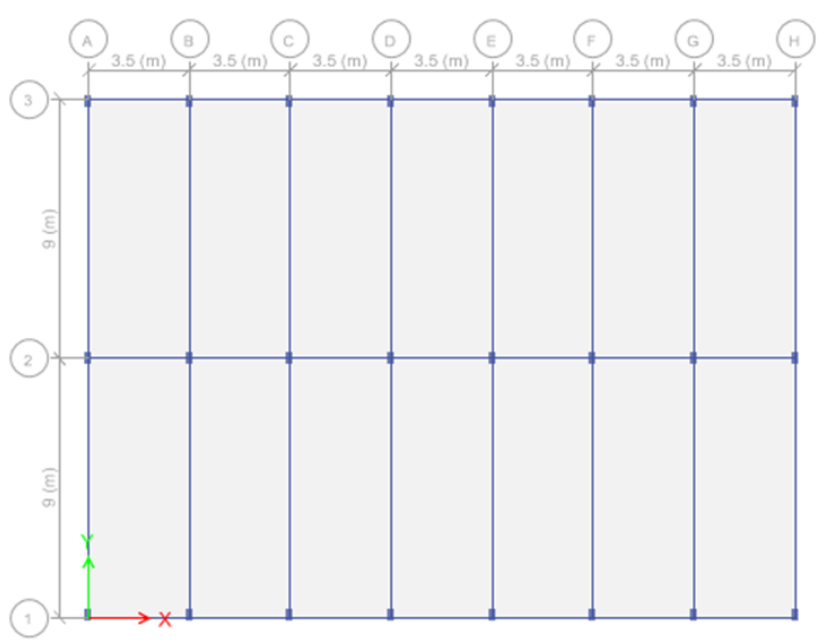

Fig 1 Plan of Symmetric Building

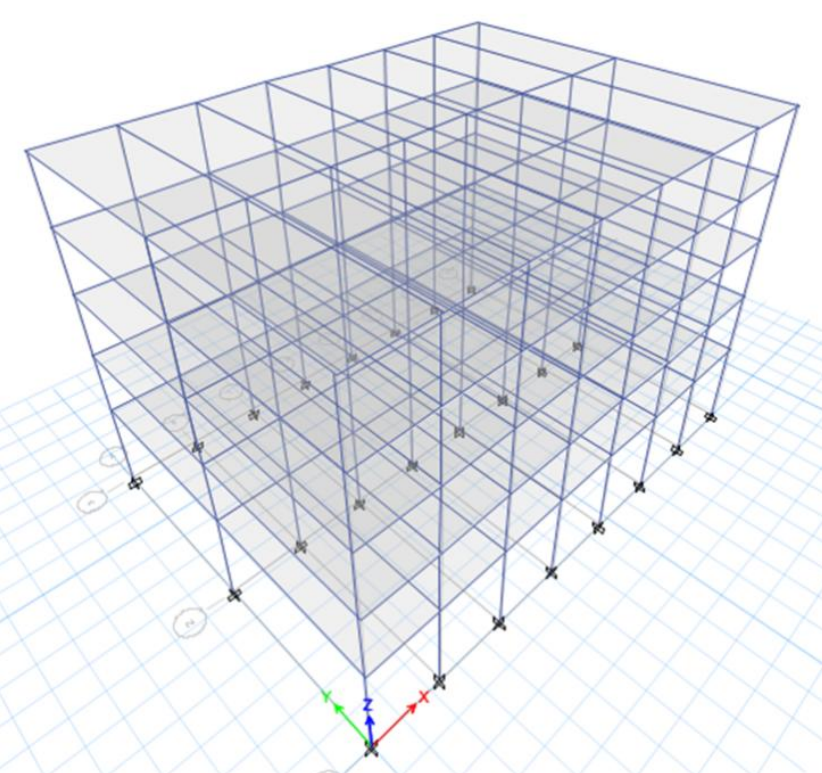

Fig 2 3D View of Symmetric Building

\subsection{Asymmetric Model}

An Asymmetrical residential building is as shown in figure below.

\begin{tabular}{|l|l|}
\hline Dimension of column & $0.23 \times 0.4 \mathrm{~m}$, \\
\hline Beam & $0.23 \times 0.35 \mathrm{~m}$ \\
\hline Thickness of slab & $0.125 \mathrm{~m}$ \\
\hline Thickness of wall & $0.23 \mathrm{~m}$ \\
\hline Soil type & II \\
\hline Live load & $2 \mathrm{KN} / \mathrm{m}$ \\
\hline Location of Building & Mysore, Karnataka, India. \\
\hline
\end{tabular}

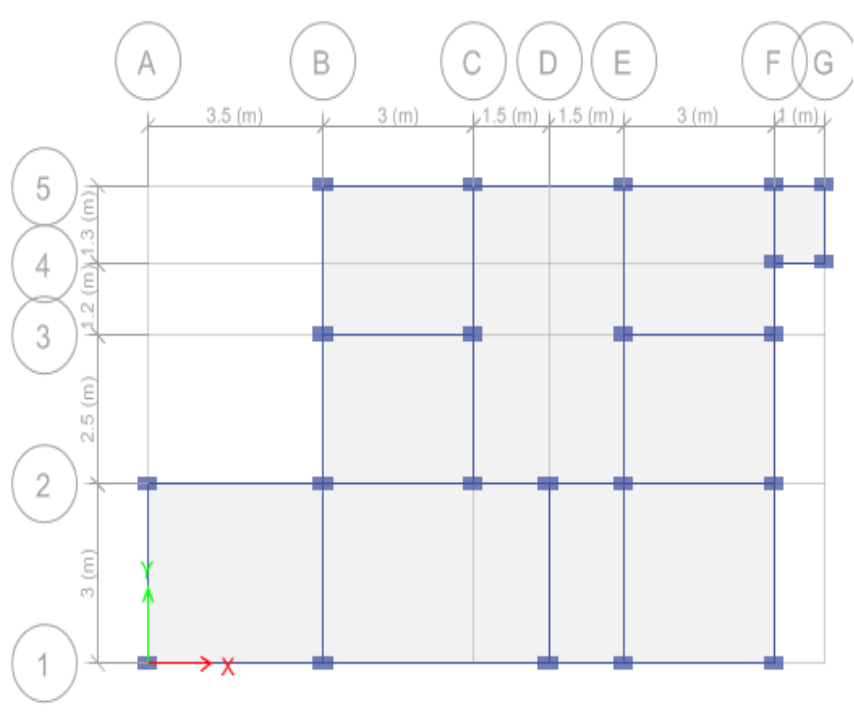

Fig 3 Plan of Asymmetric Building

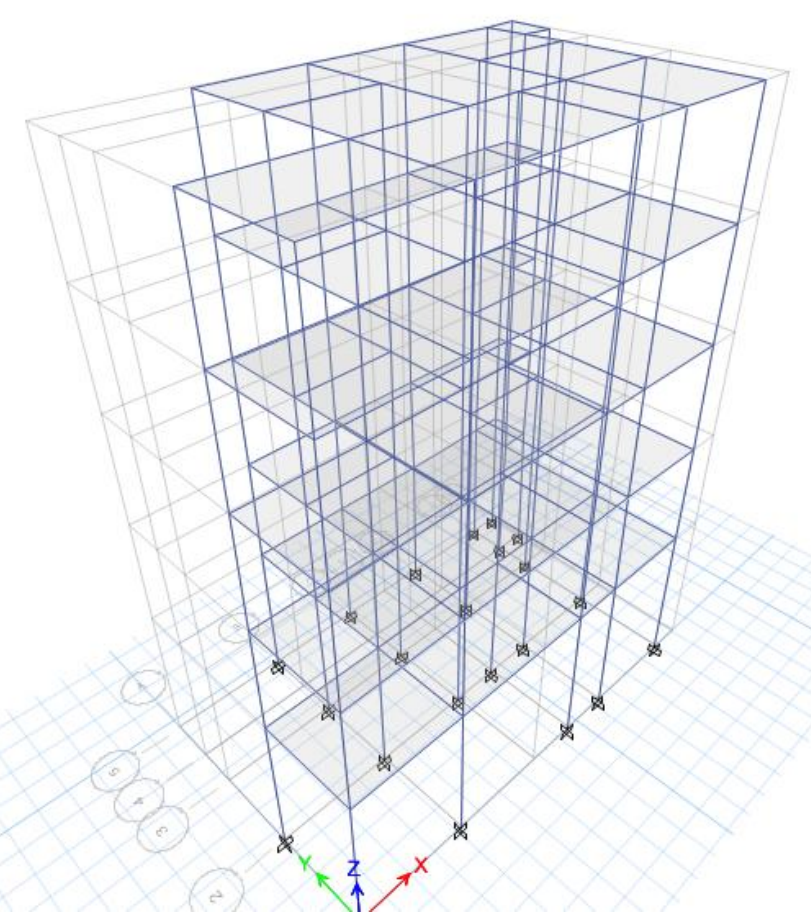

Fig 4 3D View of Asymmetric Building

\section{SUMMARY OF ANALLYSIS IN ETABS 2015}

1. Create the model with nonlinear properties.

2. Set the maximum number of modes as the number of stories multiplied by 3 for 3D Analysis.

3. Perform gravity analysis and modal analysis. From modal analysis result the direction of modes (weather $\mathrm{X}$-direction or Y-direction) are obtained.

4. In case of asymmetric structures it is needed to calculate the eccentricity ratio in each storey and apply it to lateral load pattern.

5. Define the nonlinear load case for each mode separately in $\mathrm{X}$ or $\mathrm{Y}$ direction according to the direction of mode. 
6. Perform pushover analysis and note down the maximum base shear in each mode and combine them by SRSS rule.

7. Calculate scale factor for each mode and apply them to nonlinear load cases in each mode.

8. Again perform pushover analysis, resulting base shears are combined by SRSS rule and scale factors are calculated.

9. Apply these scale factors to a separate nonlinear load case which contain all the mode in $\mathrm{X}$ and $\mathrm{Y}$ direction with above computed scale factor and perform pushover analysis.

10. From bilinear pushover curve we can obtain target displacement. Compare target and monitored displacement with applied displacement in the nonlinear load case, if target displacement is more than applied load case then apply target displacement as applied load and perform the final pushover analysis.

11. Calculate damage index for the structure from the pushover curve results using,

$$
\begin{gathered}
D_{1}=\frac{E-E_{i e}}{E_{T}-E_{i e}} \times 100 \\
D_{2}=\frac{E-E_{e}}{E_{T}-E_{i e}} \times 100 \\
D_{3}=\frac{E_{L}-E_{N L}}{E_{L T}-E_{N L T}} \times 100
\end{gathered}
$$

Where,

$D_{1}, D_{2}$ and $D_{3}$ Are Damage index for method 1, method 2 and method 3 respectively.

$\mathrm{E}=$ Energy dissipated at which damage is being estimated,

$E_{i e}=$ Initial yield energy of structure;

$E_{T}=$ Total energy absorbed by structure;

$E_{e}=$ Instantaneous elastic energy at which damage is being estimated

$E_{L}=$ Linear energy at displacement level at which damage is being estimated;

$E_{N L}=$ Nonlinear energy at which damage is being estimated; $E_{L T}=$ Linear energy at maximum displacement of structure;

$E_{N L T}=$ Nonlinear energy at maximum displacement of structure

\section{RESULTS AND DISCUSSIONS}

\subsection{Pushover Curve Results}

The $1^{\text {st }}$ mode reaches ultimate yielding point at $181.7 \mathrm{~mm}$, 1216.5638 KN whereas final combined load case reach ultimate yielding point at $105.3 \mathrm{~mm}, 98.4257 \mathrm{KN}$. Here it can be observed that by considering all the modes, the capacity of the structure is decreased by $43 \%$ when compared with only one mode. Hence adopting spectra based adaptive multimode analysis is very useful in getting accuracy of the results which include all the modes.

Ductility of symmetric building is more when compared to asymmetric structure.
Symmetric structure shows post yielding behavior and also strength degradation behavior.

Asymmetric structure is showing post yielding behavior but there is no strength degradation behavior this shows that asymmetric structure is undergoing brittle failure of structural members.

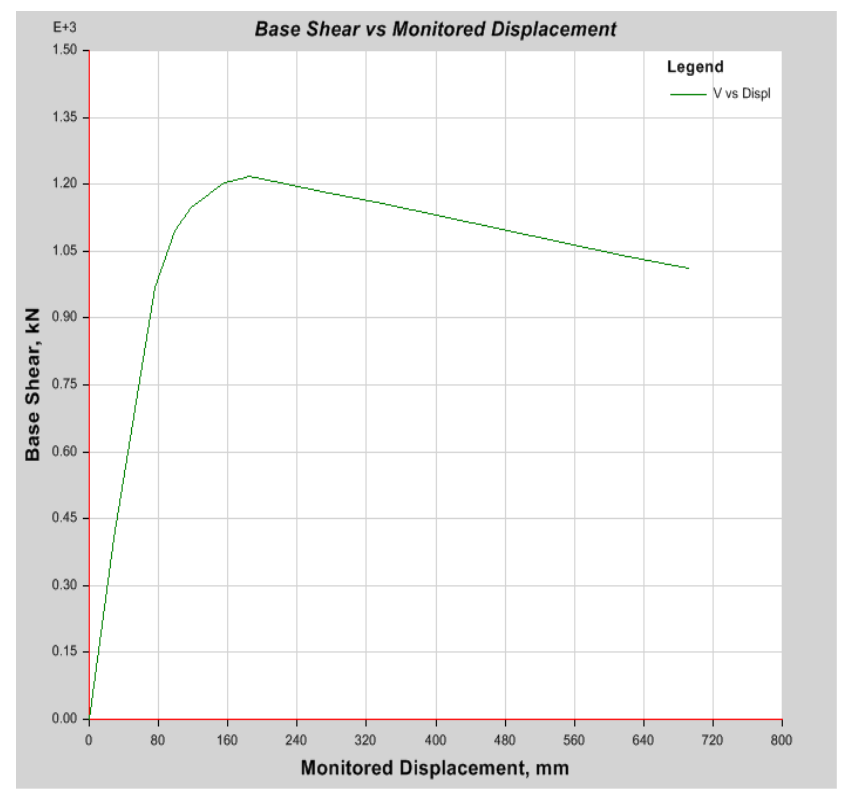

Fig 5 Pushover Curve For Symmetrical Structure At Mode1 In X-Direction

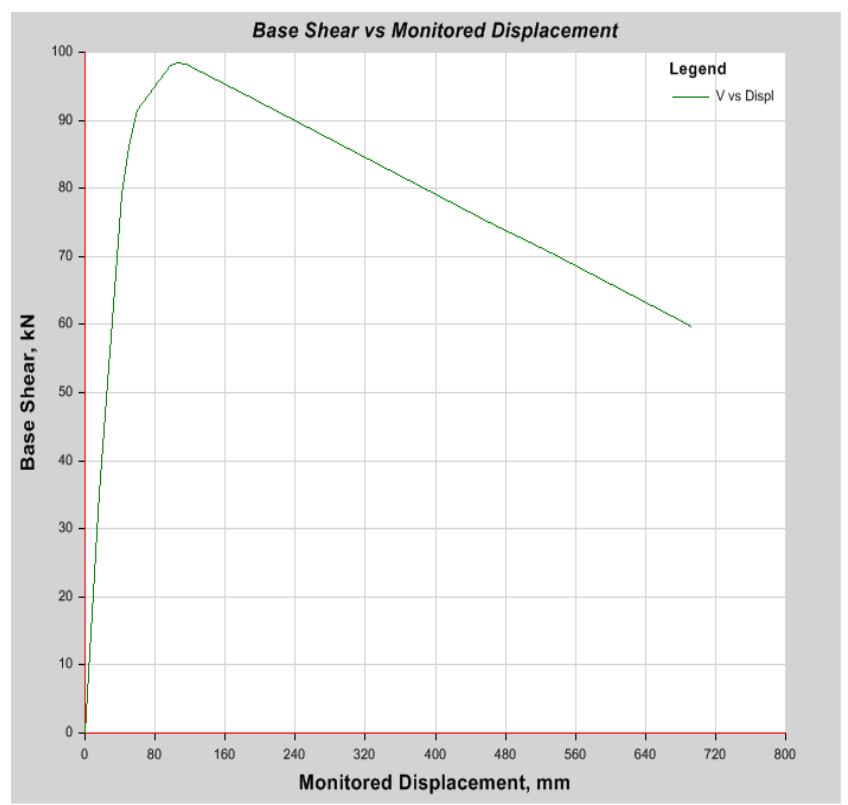

Fig 6 Pushover Curve For Symmetrical Structure By Combining All Modes In X-Direction 


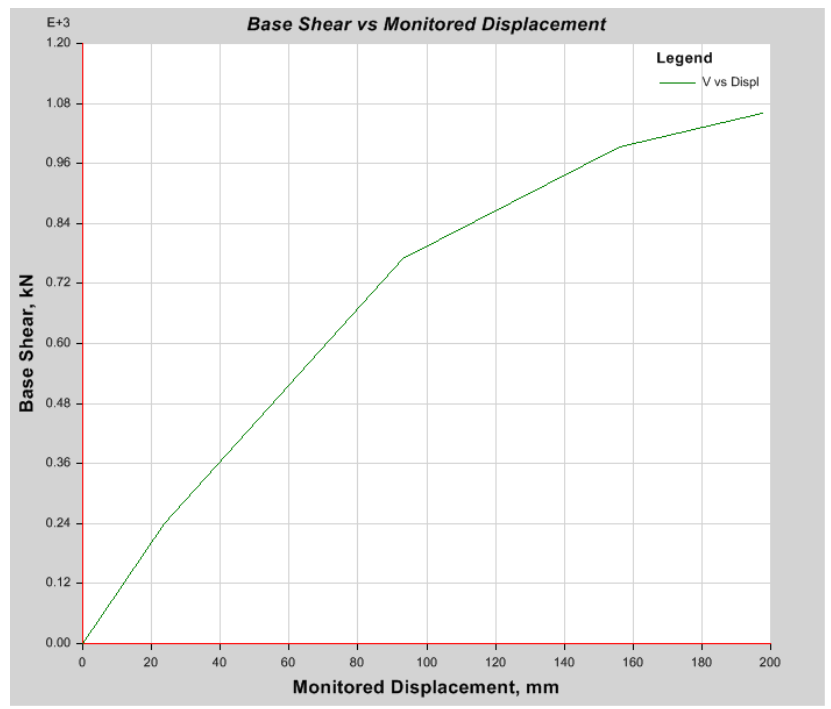

Fig 7 Pushover Curve For Asymmetrical Structure At Mode-1 In Y-Direction

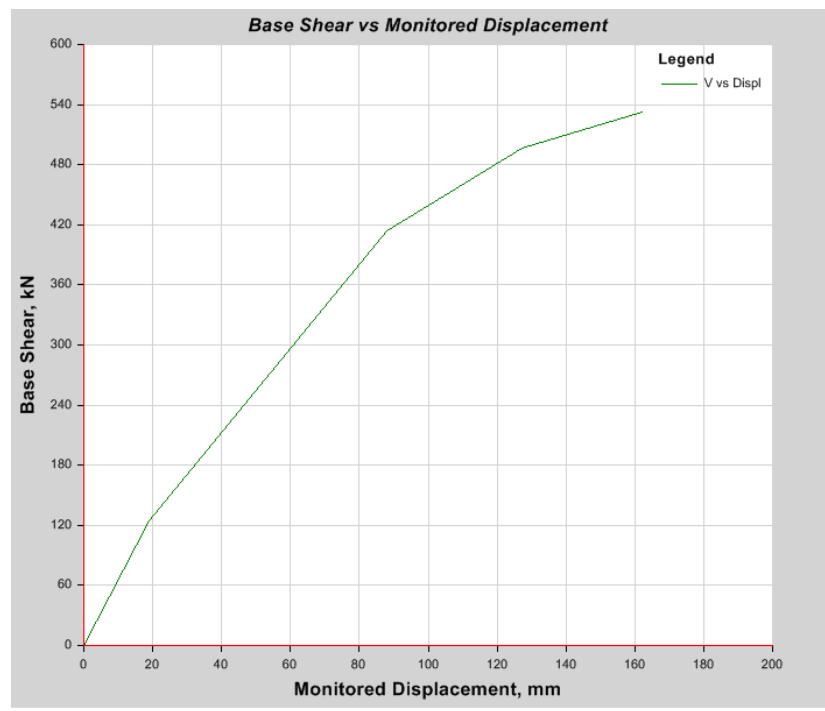

Fig 8 Pushover Curve For Asymmetrical Structure With Combined Loading In Y-Direction

\section{2 $S_{\mathrm{a}}$ vs $S_{\mathrm{d}}$ Curve Results}

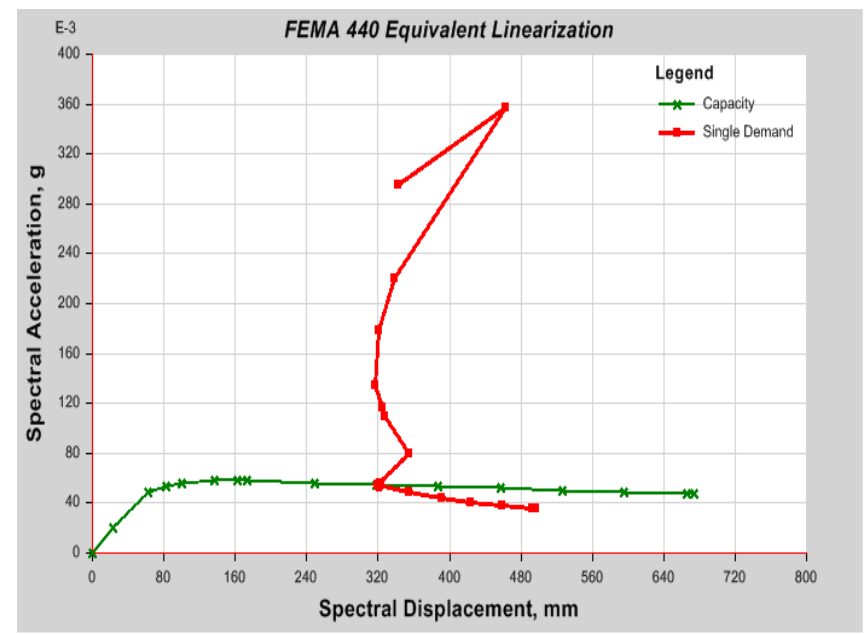

Fig $9 \mathrm{~S}_{\mathrm{a}}$ vs $\mathrm{S}_{\mathrm{d}}$ Curve For Symmetric Structure At Mode-1 In $\mathrm{X}$-Direction

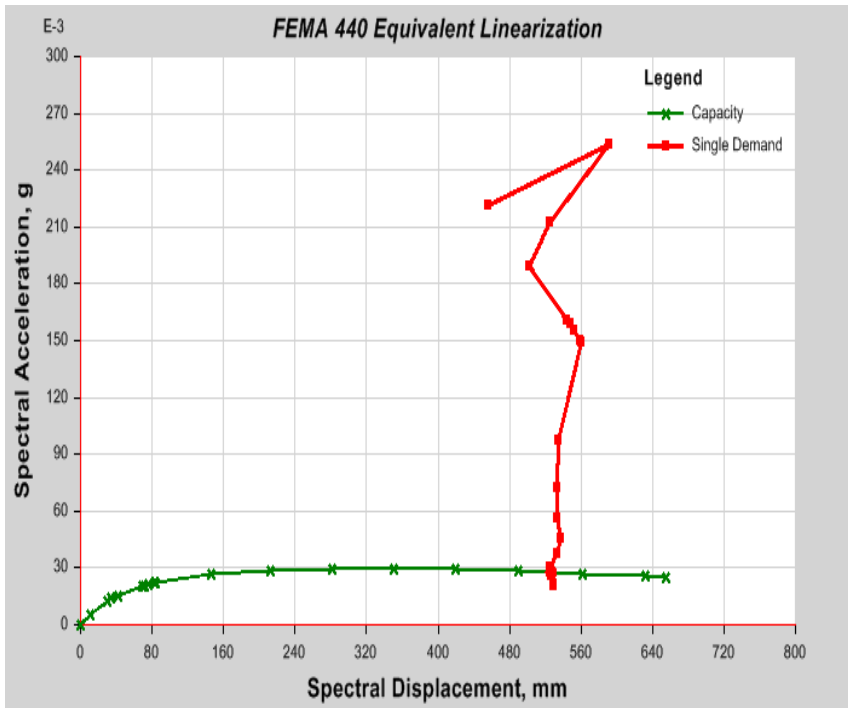

Fig $10 \mathrm{~S}_{\mathrm{a}}$ vs $\mathrm{S}_{\mathrm{d}}$ Curve For Symmetric Structure For Combined Load Case In X-Direction

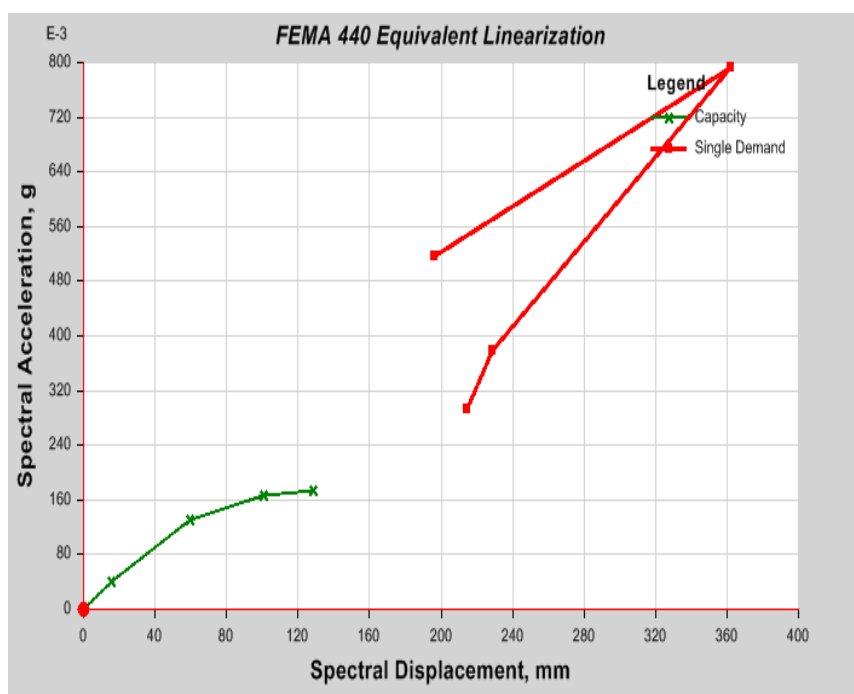

Fig $11 \mathrm{~S}_{\mathrm{a}}$ vs $\mathrm{S}_{\mathrm{d}}$ Curve For Asymmetric Structre At Mode-1 In Y-Direction

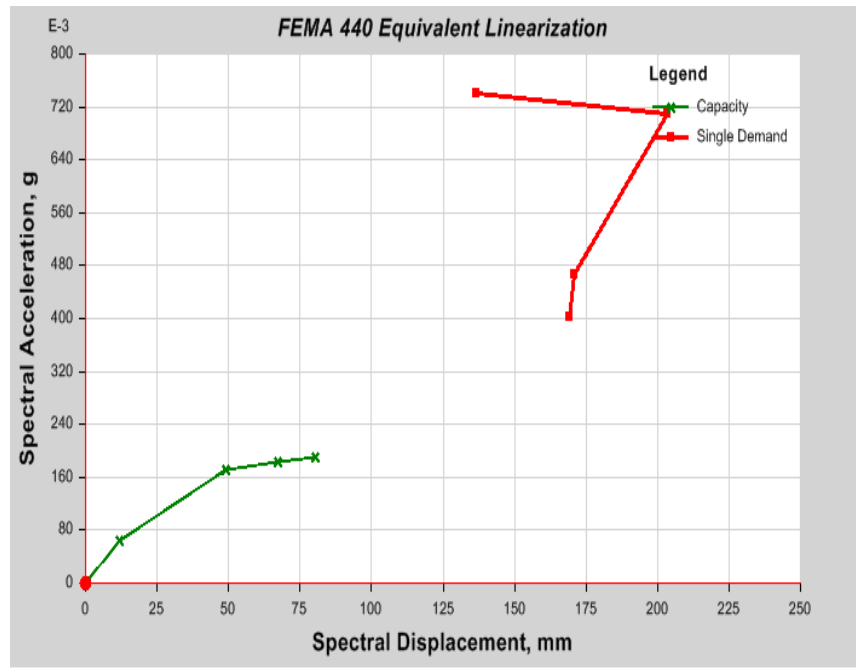

Fig $12 \mathrm{~S}_{\mathrm{a}}$ vs $\mathrm{S}_{\mathrm{d}}$ Curve For Asymmetric Structure For Combined Load Case In Y-Direction 
In symmetric structure the performance point is found only in mode-1. The displacement at performance point in mode1 is $340.8 \mathrm{~mm}$. and in all modes the displacement at performance point $565.9 \mathrm{~mm}$ which means participation of mode- 1 in the analysis is more than any other modes. But other $40 \%$ cannot be neglected, thus we need to consider all the modes for combined effect.

In asymmetric structure the performance point is found only in mode- 4 . The maximum displacement occurred in mode- 4 is $34.3 \mathrm{~mm}$. In final result also there is no meet of point observed. Therefore it is very much necessary to adopt spectra based adaptive multimodal pushover procedure to know the changes in behavior of structure at different modes. Hence this method help to choose peak performance results for the design of structure.

From the above results the capacity of the symmetric structure is greater when compared with asymmetric structure.

\subsection{Bilinear Curve Results}

Target displacements obtained are used in the design of structure.

In symmetric model first mode represents the target displacement of $378.3 \mathrm{~mm}$ whereas all modes combined final target displacement is $523.4 \mathrm{~mm}$. Here it can be observed that $27 \%$ less target displacement is obtained when considering only $1^{\text {st }}$ mode. Therefore considering all the mode is important to get accurate results and good design.

In symmetric model the target displacement is within the capacity of the structure whereas in asymmetric model the target displacement is beyond the capacity of the structure.

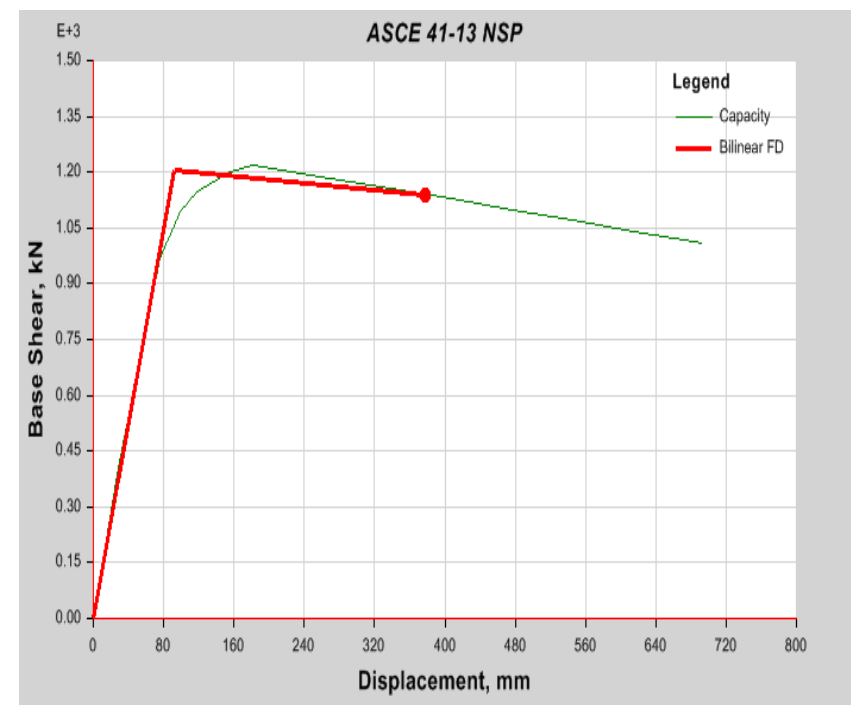

Fig 13 Bilinear Pushover Curve For Symmetric Structure At Mode-1 In X-Direction

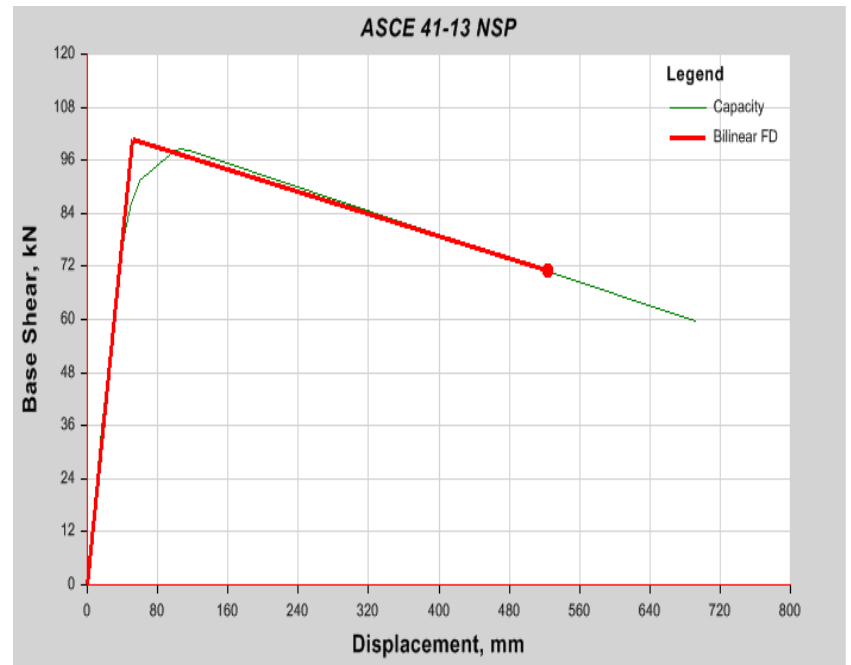

Fig 14 Bilinear Pushover Curve For Symmetric Structure For Combined Load Case In X-Direction

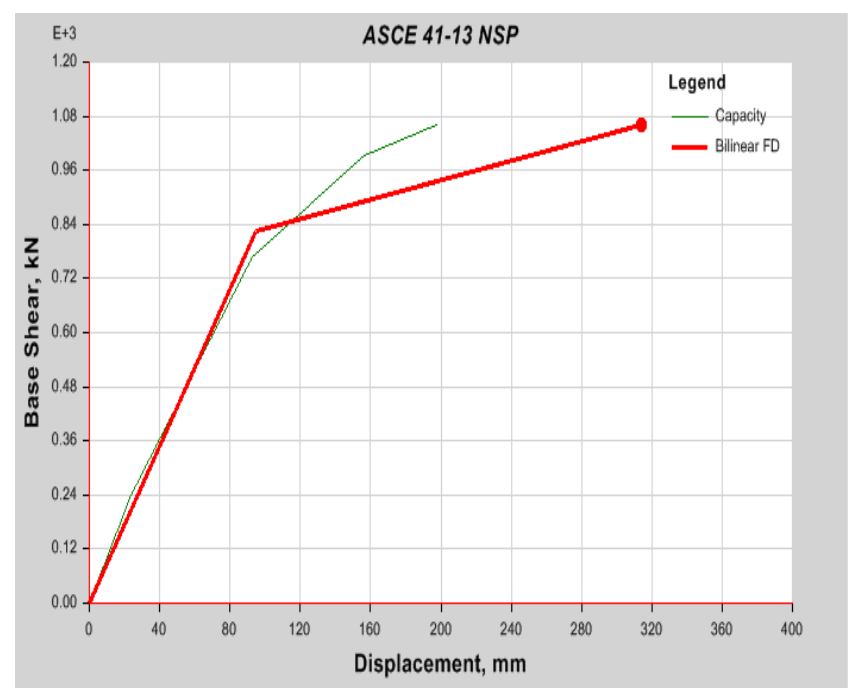

Fig 15 Bilinear Pushover Curve For Asymmetric Structure At Mode-1 In Y-Direction

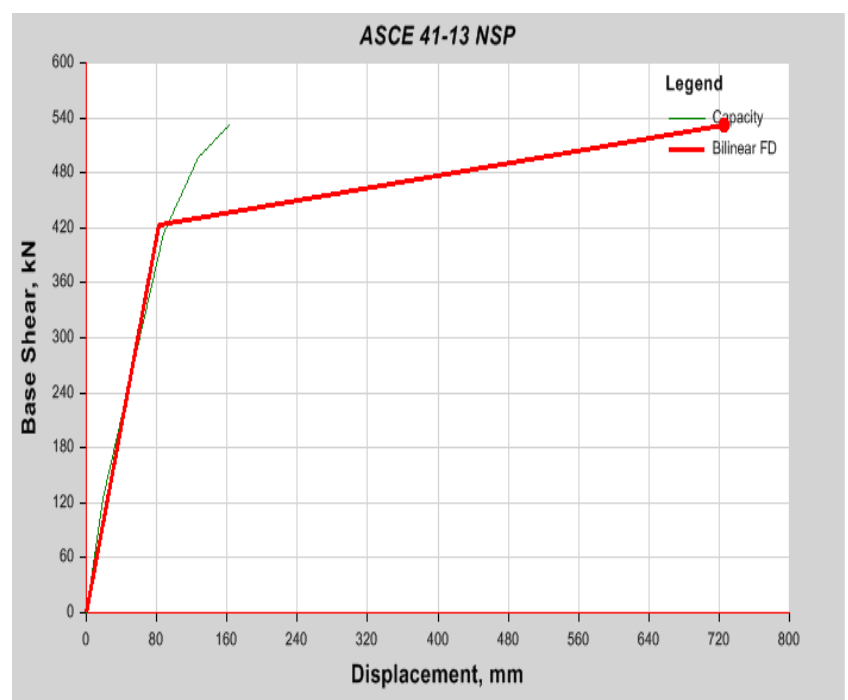

Fig 16 Bilinear Pushover Curve For Asymmetric Structure For Combined Load Case In Y-Direction 


\subsection{Hinge State Results}

Table 1 Performance Level

\begin{tabular}{|l|l|}
\hline $\begin{array}{l}\text { PERFORMANCE } \\
\text { LEVEL }\end{array}$ & DESCRIPTION \\
\hline Operational Level (OL) & $\begin{array}{l}\text { Building will be under } \\
\text { construction. Minor repairs may } \\
\text { be required. }\end{array}$ \\
\hline $\begin{array}{l}\text { Immediate occupancy } \\
\text { level (IO) }\end{array}$ & $\begin{array}{l}\text { Building will be available to } \\
\text { accommodate. }\end{array}$ \\
\hline Life safety level (LS) & $\begin{array}{l}\text { Very low chances of collapse of } \\
\text { structural members. } \\
\text { No harm to life occurs. }\end{array}$ \\
\hline $\begin{array}{l}\text { Collapse prevention } \\
\text { level (CP) }\end{array}$ & $\begin{array}{l}\text { This requires stability under } \\
\text { vertical loads. }\end{array}$ \\
\hline
\end{tabular}

1. 3-D View - Displacements (PX15-1) Step 16/16 [mm]

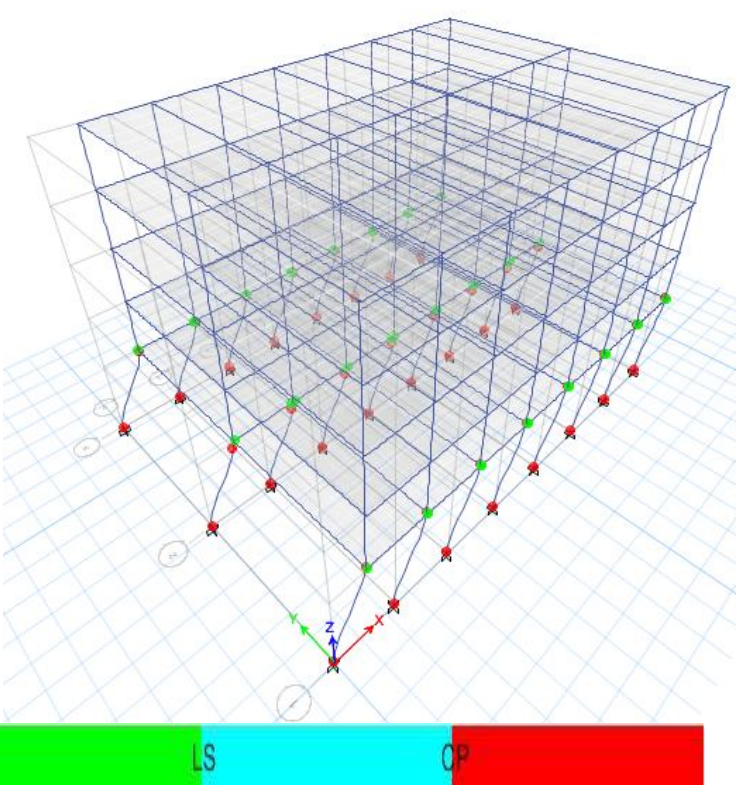

Fig 17 Hinge State For Symmetrical Structure At Mode-1 in $X$-Direction

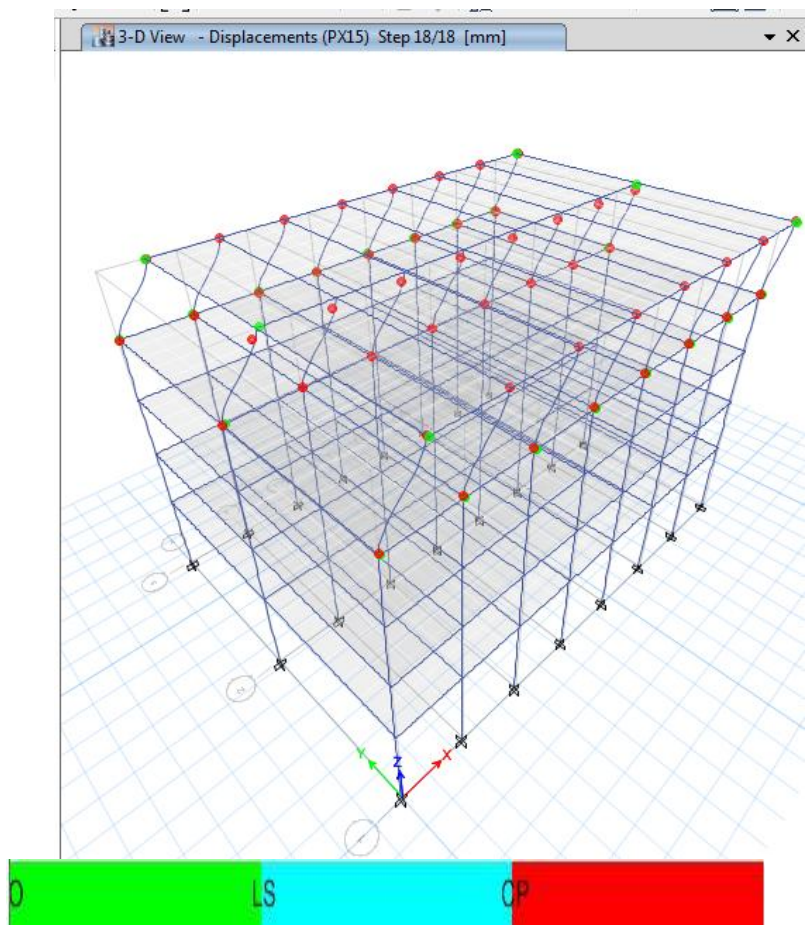

Fig 18 Hinge State For Symmetrical Structure For Combined Load Case In $X$-Direction

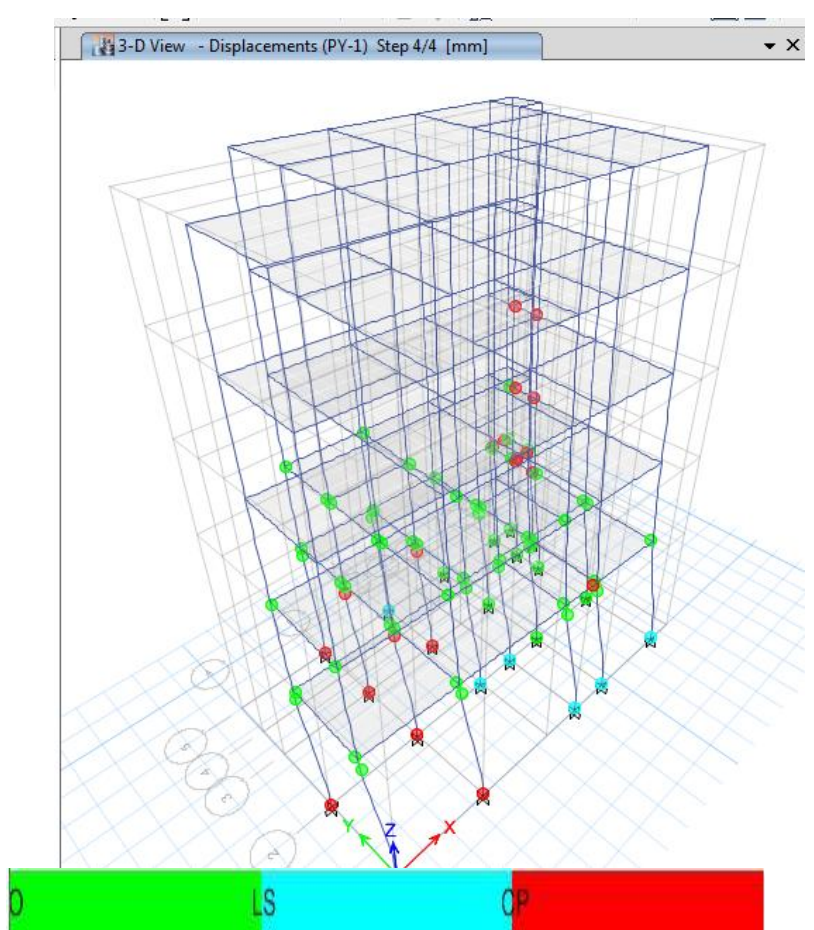

Fig 19 Hinge State For Asymmetrical Structure At Mode-1 In $Y$-Direction 


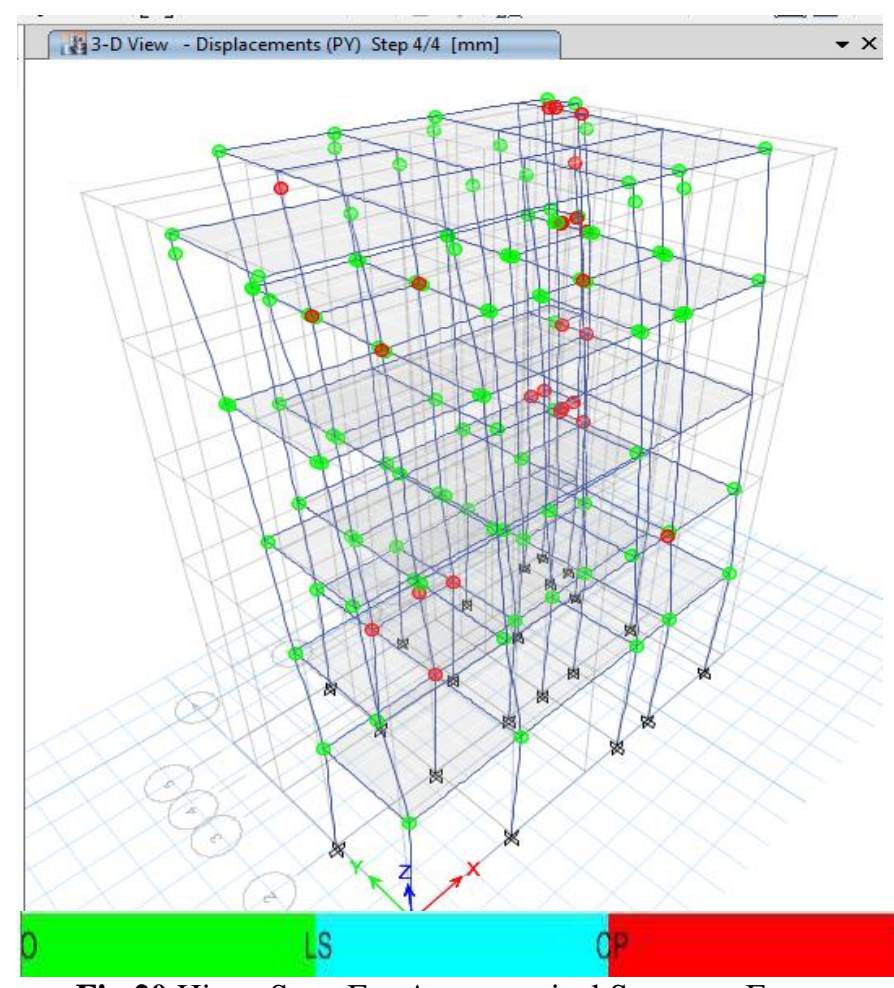

Fig 20 Hinge State For Asymmetrical Structure For Combined Load Case In Y-Direction

In symmetrical structure, the first mode contain total of 1165 hinges of which 1075 hinges are in immediate occupancy level, 42 hinges are in life safety level, 0 in collapse prevention level and 48 are beyond collapse prevention level. When all modes combined case results contain total of 1165 hinges of which 1081 hinges are in immediate occupancy level, 36 hinges are in life safety level, 0 in collapse prevention level and 48 are beyond collapse prevention level.

Thus in spectra based adaptive multimodal analysis, the behavior of the structure in every single step of analysis can be observed.

The failure of hinges occurs first where the columns are placed closely. Therefore columns should be placed at equal distances as far as possible.

The failure of hinges starts at bottom storey and gradually transfers to upper stories with each mode.

\subsection{Damage Index Results}

Table 2 Ranges Of Damage Index (Dorde Ladinovic,

Aleksandra Radujkovic, Andrija Raseta (2011) [16])

\begin{tabular}{|l|l|l|}
\hline Degree of damage & Damage index & State of structure \\
\hline Minor & $0.0-0.2$ & Serviceable \\
\hline Moderate & $0.2-0.5$ & Repairable \\
\hline Severe & $0.5-1.0$ & Irreparable \\
\hline Collapse & $>1.0$ & Loss of building \\
\hline
\end{tabular}

Table 3 Damage Index For Symmetric Structure

\begin{tabular}{|c|c|c|c|}
\hline \multicolumn{4}{|c|}{ DAMAGE INDEX FOR SYMMETRICAL STRUCTURE } \\
\hline Mode no. & $\begin{array}{l}\text { METHOD } \\
1\end{array}$ & $\begin{array}{l}\text { METHOD } \\
2\end{array}$ & $\begin{array}{l}\text { METHOD } \\
3\end{array}$ \\
\hline PX1 & 0.230776 & 0.166491 & 0.023737 \\
\hline PX4 & 0.162262 & 0.131261 & 0.016884 \\
\hline PX7 & 1 & 0.004032 & 1 \\
\hline PX10 & 0.14566 & 0.135823 & 0.013773 \\
\hline PX11 & 0.947425 & 0.23723 & 2.468422 \\
\hline PY2 & 0.966751 & 0.732177 & 1.072819 \\
\hline PY5 & 1 & 0.269953 & 1 \\
\hline PY8 & 1 & 0.185354 & 0.28759 \\
\hline PY13 & 1 & 0.819354 & 1 \\
\hline PY14 & 0.809682 & 0.33357 & 2.834754 \\
\hline $\begin{array}{l}\text { OVERALL } \\
\text { DAMAGE } \\
\text { INDEX IN } \\
\text { X-DIRECTION }\end{array}$ & 0.1362 & 0.09985 & 0.01345 \\
\hline $\begin{array}{l}\text { OVERALL } \\
\text { DAMAGE } \\
\text { INDEX IN } \\
\text { Y-DIRECTION }\end{array}$ & 0.6663 & 0.1907 & 0.5262 \\
\hline
\end{tabular}

Table 4 Damage Index For Asymmetric Structure

\begin{tabular}{|c|c|c|c|}
\hline \multicolumn{4}{|c|}{$\begin{array}{lll}\text { DAMAGE INDEX } & \text { FOR } \\
\text { STRUCTURE } & & \\
\end{array}$} \\
\hline Mode no. & $\begin{array}{l}\text { METH } \\
\text { OD } 1\end{array}$ & $\begin{array}{l}\text { METHOD } \\
2\end{array}$ & $\begin{array}{l}\text { METHOD } \\
3\end{array}$ \\
\hline PX3 & $\begin{array}{l}0.3490 \\
08\end{array}$ & 0.347986 & 2.274995 \\
\hline PX6 & 1 & 0.680699 & 1 \\
\hline PX10 & 1 & 0.124079 & 1 \\
\hline PX13 & 1 & 0.516721 & 1 \\
\hline PX15 & $\begin{array}{l}0.9322 \\
06\end{array}$ & 0.580708 & 0.76984 \\
\hline PY1 & 1 & 0.601102 & 1 \\
\hline PY4 & 1 & 0.677741 & 1 \\
\hline PY7 & 1 & N/A & 1 \\
\hline PY9 & $\begin{array}{l}0.5712 \\
56\end{array}$ & 0.432167 & 1.42617 \\
\hline PY11 & $\begin{array}{l}0.8492 \\
1\end{array}$ & 0.745895 & 1.086192 \\
\hline $\begin{array}{l}\text { OVERALL } \\
\text { DAMAGE } \\
\text { INDEX IN } \\
\text { X-DIRECTION }\end{array}$ & 1 & 0.52 & 1 \\
\hline $\begin{array}{l}\text { OVERALL } \\
\text { DAMAGE } \\
\text { INDEX IN } \\
\text { Y-DIRECTION }\end{array}$ & 1 & 0.628 & 1 \\
\hline
\end{tabular}


The higher value of damage index is observed in all modes combined case when compared with the damage index by considering only $1^{\text {st }}$ mode. Therefore to get accurate results, all the modes need to be considered.

The severe and collapsed state is observed more in asymmetric model than symmetric model. Therefore as the asymmetry increases the damage also increase.

Out of three methods, the Method 1 and Method 3 is indicating little higher degree of damage when compared with Method 2.

\section{CONCLUSION}

From the pushover curve results it is observed that the capacity of the structure obtained by considering all modes is less than the capacity obtained by considering only $1^{\text {st }}$ mode. Hence adopting spectra based adaptive multimode analysis is very useful in getting more accurate results.

By adopting asymmetric structure over symmetric structure the ductility of structure may be compromised. Hence suitable precautionary measures should be taken while adopting asymmetric structures.

In symmetric model the capacity is meeting the demand of the building where as in asymmetric model the demand is very high. Thus we can conclude that, as the asymmetry of structure increases the capacity of the structure decreases.

From bilinear curve results it is observe that target displacement obtained considering only $1^{\text {st }}$ mode is less than the target displacement obtained considering all modes. Therefore considering all the modes is important to get accurate results and good design.

More number of hinges reach failure in asymmetric model when compared with symmetric model. Failure occurs early where columns are placed closely. Therefore columns should be placed at equal interval as far as possible.

The higher value of damage index is obtained by considering all modes when compared with considering only $1^{\text {st }}$ mode. Therefore to get accurate results we need to consider all the modes.

The severe and collapsed state of damage is observed more in asymmetric model than in symmetric model. Therefore as the asymmetry increases the damage also increase.

Out of three methods of damage index, the Method 1 and Method 3 is indicating little higher degree of damage when compared with Method 2.

\section{REFERENCES}

[1] IS 1893 (Part 1): 2002, Criteria for earthquake resistant design of structures. Bureau of Indian Standard, Manak Bhavan, New Delhi, India.
[2] Rahul Rana, Limin Jin, and Atila Zekioglu (2004). Pushover analysis of a 19 storey concrete shear wall building. $13^{\text {th }}$ world conference on earthquake engineering, Vancouver B.C Canada.

[3] K. Shakeri, M.A. Shayanfar and M. Mohebbi Asbmarz (2008). A SPECTRA-BASED MULTI MODAL ADAPTIVE PUSHOVER PROCEDURE FOR SEISMIC ASSESSMENT OF BUILDINGS. The $14^{\text {th }}$ World Conference on Earthquake Engineering October 12-17, 2008, Beijing, China.

[4] Yousuf Dinar, Md. Imam Hossain, Rajib Kumar Biswas, Md. Masud Rana. Descriptive study of pushover analysis in RCC structures of rigid joint. IOSR Journal of Mechanical and Civil Engineering (IOSR JMCE) ISSN: 2278-1684 Volume 11, Issue 1 (January-February), PP 60-68.

[5] J.R. Qian, W.J. Zhang, and X.D. Ji (2008). Application of pushover analysis on earthquake response predication of complex large-span steel structures. The $14^{\text {th }}$ World Conference on Earthquake Engineering October 12-17, 2008, Beijing, China.

[6] Philip DE GUZMAN1 and Yuji ISHIYAMA (2004). Collapse assessment of building structures using damage index. 13th World Conference on Earthquake Engineering Vancouver, B.C., Canada August 1-6, 2004 Paper No. 0734.

[7] Tathagata Roy and Dr. Pankaj Agarwal (2014). Damage Index of Reinforced Concrete Structures in India. International Journal of Research (IJR) Vol-1, Issue-5, June 2014.

[8] Saurabh Shiradhonkar and Ravi Sinha (2012). Detailed evaluation of available seismic damage indices. A project report, IITR.

[9] Sumit R. Thakur, Sudhir P.Patil, Dr.Keshav K.Sanagle. Evaluation of damage index of high rise building using nonlinear static seismic analysis. International Journal of Emerging Technology and Advanced Engineering Volume 2, Issue 10, October 2012.

[10] ANTHUGARI VIMALA and PRADEEP KUMAR RAMANCHARLA (2014). Expended energy based damage assessment of RC bare frame using nonlinear pushover analysis. Urban Safety of Mega Cities in Asia 2014 (USMCA 2014).

[11] Chopra, A.K. and Goel, R.K. (2002). A modal pushover analysis procedure for estimating seismic demands for buildings. Earthquake Engineering and Structural Dynamics, 31, 561-582.

[12] Aydinoglu M.N. (2003). An incremental response spectrum analysis procedure based on inelastic spectral displacements for multi-mode seismic performance evaluation. Bulletin of Earthquake Engineering, 1, 336.

[13] Kalkan, E. and Kunnath S.K. (2006). Adaptive modal combination procedure for nonlinear static analysis of building structures. Journal of Structural Engineering, ASCE, 132:11, 1721-1731.

[14] R. Sinha \& S. R. Shiradhonkar. Seismic Damage Index for Classification of Structural Damage - Closing the Loop. $15^{\text {th }}$ World Conference on Earthquake Engineering, Lisboa 2012. 
[15] Young J. Park, Anderi M. Reiniorn, and Shashi K. Kunnath. Seismic damage analysis of reinforced concrete buildings. $9^{\text {th }}$ World Conference on Earthquake Engineering, August 2-9, 1988, TokyoKyoto, Japan (Vol. VII).

[16] Dorde Ladinovic, Aleksandra Radujkovic, Andrija Raseta. Seismic performance assessment based on damage of structures - part 1: theory. FACTA UNIVERSITATIS Series: Architecture and Civil Engineering Vol. 9, No 1, 2011, pp. 77 - 88

\section{BIOGRAPHIES}

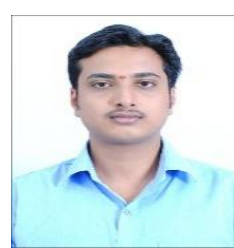

Mr. Pavan Kumar N, is a Final Year PG Student, pursuing his Master of Technology in Structural Engineering from BGS Institute of Technology, Mandya District, Karnataka, India.

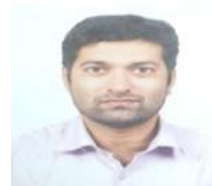

Mr. Avinash Gornale BE, M.Tech is working as an Assistant Professor in department of civil engineering in Maharaja Institute of Technology, Mysore, Karnataka. His areas of research interest include Earthquake engineering and Performance Evaluation.

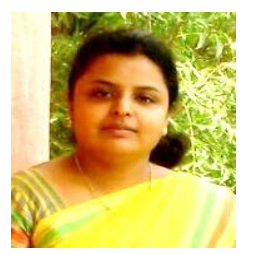

Ms. Gargi G S BE, M.Tech is working as an Assistant Professor in department of civil engineering in BGS Institute of Technology, Mandya District, Karnataka, India. BE and M.Tech in CAD Structures from PES, Mandya.

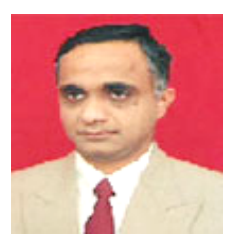

Dr. B G Naresh Kumar B.E., M.E., Ph.D. working as Principal in Maharaja Institute of Technology, Mysore, Karnataka. ME \& Ph.D. from IIT Kharagpur. In the past he worked as Legal Advisor for AICTE, New Delhi. 